УДК 67.017

\title{
ВЛИЯНИЕ ТЕМПЕРАТУРЫ АНОДНОЙ ЭЛЕКТРОЛИТНО- ПЛАЗМЕННОЙ ЦЕМЕНТАЦИИ НА КОМПЛЕКС СВОЙСТВ СТАЛИ 20
}

\author{
Буров Семён Владимирович \\ Табачникова Любовь Владимировна \\ Аспиранты \\ ФГБОУ ВО Костромской государственный университет
}

Аннотация: в работе рассмотрены свойства стали 20 после анодной электролитно-плазменной цементации, а также влияние температуры обработки на морфологию, фазовый состав, микротвердость и коррозионную стойкость поверхности образцов стали 20.

Ключевые слова: анодная электролитно-плазменная цементация, шероховатость, фазовый состав, диффузионный слой, микротвердость, коррозионная стойкость.

\section{INFLUENCE OF THE TEMPERATURE OF ANODE ELECTROLYTIC- PLASMA CARBURIZING ON THE COMPLEX OF PROPERTIES OF STEEL 20}

\section{Burov Semyon Vladimirovich Tabachnikova Lyubov Vladimirovna}

\begin{abstract}
: in the research there're reviewed the properties of anode electrolytic-plasma carburizing steel 20 , and the influence of treatment temperature on the morphology, phase composition, microhardness and corrosion resistance of steel 20 surface.

Key words: anode electrolytic-plasma carburizing, roughness, phase composition, diffusion layer, microhardness, corrosion resistance.

\section{Введение}

Цементованную сталь 20 применяют для производства как малонагруженных деталей, так и деталей, которым требуется высокая поверхностная прочность. При этом сохраняется достаточная пластичность 275
\end{abstract}


сердцевины деталей. Выбор марки стали обоснован еще и тем, что в силу своего состава при ее нагреве и быстром охлаждении в сердцевине не происходит фазовых переходов, связных с образованием мартенсита. Свойства поверхностного слоя будут определяться скоростью охлаждения и распределением углерода в нем.

Анодное электролитно-плазменное насыщение является перспективным направлением увеличения ресурса изделий из сталей с сохранением и даже повышением коррозионных свойств за счёт формирования на поверхности детали модифицированных слоёв. Электролитно-плазменный нагрев относится к методам скоростной химико-термической обработки (ХTO) металлов и сплавов. Явление анодного электролитно-плазменного нагрева состоит в разогреве и вскипании электролита в прианодной области с образованием сплошной и устойчивой парогазовой оболочки (ПГО), отделяющей металл от непосредственного контакта с электролитом. При этом образец нагревается до температур в диапазоне от 550 до $1000{ }^{\circ} \mathrm{C}$, позволяющих проводить насыщение поверхности легкими элементами (азотом, углеродом, кислородом).

На поверхности раздела анод - ПГО протекают процессы окисления и растворения материала анода, а также его насыщения, например, углеродом при проведении цементации. Уменьшение массы стальных образцов за счет анодного растворения всегда превышает прирост массы при окислении поверхности [1, с. 83-89]. Положительным технологическим результатом анодного растворения является снижение шероховатости поверхности обрабатываемой стальной детали, закругление кромок и снятие заусенцев [2, с. 140].

Целью работы является определение влияния режимов анодной электролитно-плазменной цементации малоуглеродистой стали 20 на комплекс свойств поверхностного слоя.

\section{Методы и материалы работы}

Схема установки для электролитно-плазменного нагрева представлена на рис. 1. Анодом (3) является исследуемый образец, катодом - рабочая камера (2). Рабочий электролит подаётся при помощи насоса (7) снизу вверх через рабочую камеру, электролит проходит через теплообменник (6), где охлаждается до температуры $20 \pm 1{ }^{\circ} \mathrm{C}$. Анод и катод подключаются к источнику постоянного тока (4). При подаче на систему постоянного напряжения свыше 100-150 В у анода с малой поверхностью возникает устойчивая сплошная парогазовая оболочка (ПГО). Эмиссия анионов электролита в оболочку обеспечивает прохождение через нее электрического 
тока, который приводит к разогреву парогазовой среды и окруженного ею анода до $1100^{\circ} \mathrm{C}$. На поверхности анода образуется проницаемая оксидная пленка, через которую в оболочку уходят ионы железа (анодное растворение), поступает кислород и могут диффундировать атомы легких элементов.

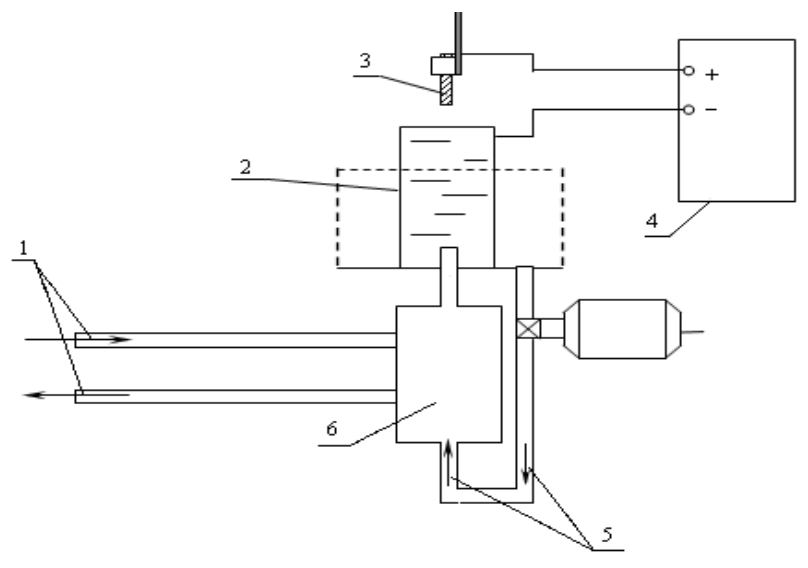

Рис. 1. Установка для электролитного нагрева: 1 - водопроводная вода; 2 рабочая камера; 3 - деталь-анод; 4 - блок питания; 5 - электролит; 6 теплообменник, 7 - насос

В данной работе скоростной электролитно-плазменной цементации (ЭПЦ) подвергалась малоуглеродистая сталь 20, из которой были изготовлены цилиндрические образцы высотой 20 мм и диаметром 11 мм. С одного торца образцов было сделано глухое технологическое отверстие глубиной 12 мм для крепления его на установке ХТО и размещения внутри хромель-алюмелевой термопары (для контроля температуры анода в ходе электролитно-плазменной обработки).

Анодная электролитно-плазменная обработка (ЭПО) проводилась в водных растворах на основе хлорида аммония и углеродсодержащих добавок. Концентрация всех компонентов - 10\% (масс.). Хлорид аммония обеспечивает достаточную электропроводность рабочих электролитов и небольшую температуру возгонки [3, с. 4-9]. В качестве доноров углерода были выбраны глицерин и сахароза. Данные компоненты обладают хорошим углеродным потенциалом, рабочие растворы имеют большой срок эксплуатации вследствие небольшой скорости выработки [4, с. 222-228].

Температура обработки изменялась от $750{ }^{\circ} \mathrm{C}$ до $950{ }^{\circ} \mathrm{C}$ с шагом $50{ }^{\circ} \mathrm{C}$. Время обработки каждого образца составляло 5 минут с последующей закалкой, которая производилась путём отключения напряжения в системе по 
окончании времени обработки. Образец, находясь в электролите, начинал быстро охлаждаться за счет конденсации оболочки и контакта с охлаждаемым электролитом.

Исследование распределения микротвёрдости по Виккерсу проводилось на микротвердомере ПМТ-3М, нормальная нагрузка составляла 50 г $(0,5 \mathrm{H})$. Значения микротвердости измерялось на следующих расстояниях от края шлифа: 10, 20, 30, 50, 70, 100 и 150 мкм. Толщину диффузионного слоя выявляли металлографическим методом после травления микрошлифов в реактиве Курпатова. При этом диффузионный слой выглядит как нетравящаяся белая полоса.

Фазовый анализ модифицированного слоя на поверхности исследуемых образцов проводился при помощи дифрактометра ДРОН-УМ1 в кобальтовом излучении Со-K $\alpha$.

Электрохимические испытания проводились методом записи потенциодинамических кривых в растворе хлорида натрия с концентрацией $3 \%$ (масс.). В начале образец выдерживался в растворе в течение 2 часов, при этом его потенциал разомкнутой цепи выходил на стационарное значение. Площадь электрохимического окна составляла $0,126 \mathrm{~cm}^{2}$. Далее снималась поляризационная кривая от $-250 \mathrm{MB}$ до $+300 \mathrm{MB}$ относительно потенциала разомкнутой цепи со скоростью $1 \mathrm{mB} / \mathrm{c}$. Расчёт плотности тока коррозии производился по уравнению Тафеля (1):

$$
\eta=a+b * \ln i
$$

где $\eta$ - перенапряжение, $i$ - плотность тока коррозии, $a$ и $b$ - константы.

Выбор коррозионной среды продиктован тем, что $3 \%$-й раствор $\mathrm{NaCl}$ является модельным по отношению к морской воде.

\section{Морфология поверхности}

После обработки в сахарозном электролите при температуре $750{ }^{\circ} \mathrm{C}$ шероховатость снижается в 2 раза по сравнению с необработанным образцом. Повышение температуры нагрева снижает эту величину до 0,25 мкм (рис. 2а.). Такая зависимость может быть связана с ростом скорости окисления поверхности образцов парами воды, дополнительным доокислением после закалки, а также повышением напряжения в системе. 

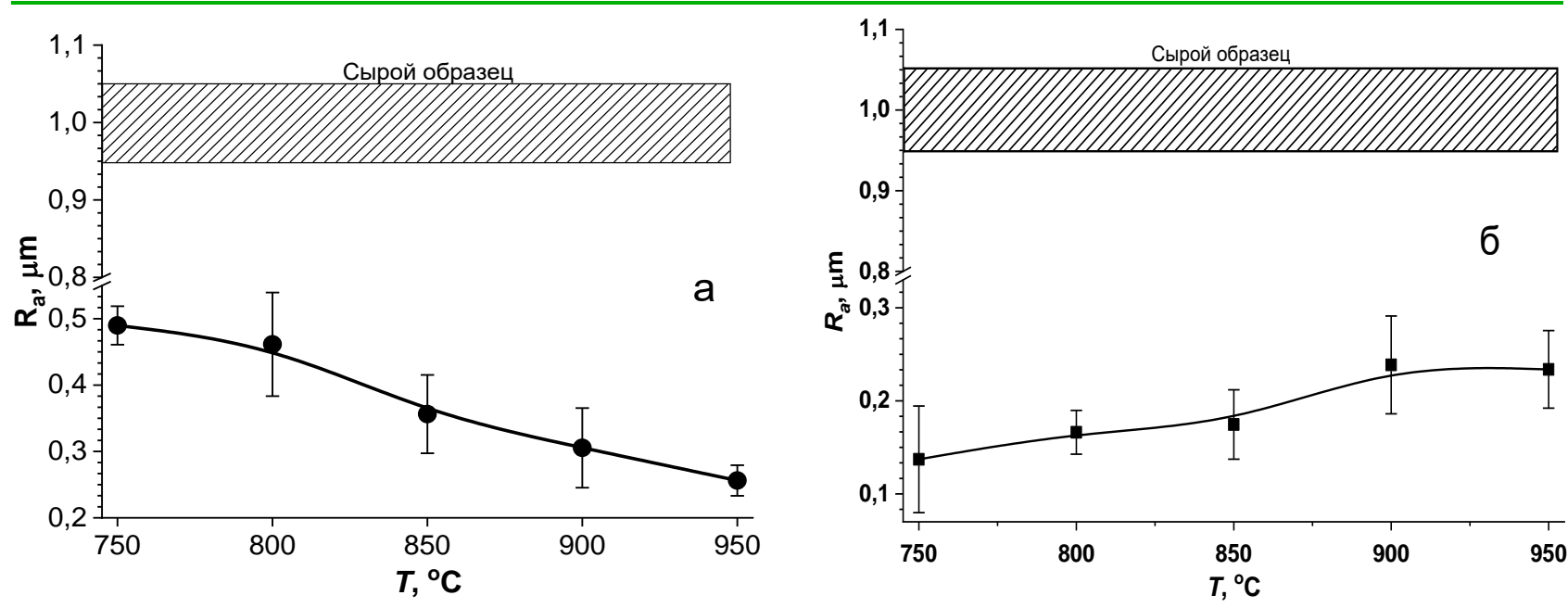

\section{Рис. 2. Зависимость шероховатости поверхности образцов стали 20 после}

АЭПЦ в электролите с добавлением сахарозы (а) и глицерина (б) от температуры обработки. Тип охлаждения - закалка

АЭПЦ в растворе с добавлением глицерина (рис. 2б) даёт иные результаты: при температуре обработки $750{ }^{\circ} \mathrm{C}$ шероховатость снижается до 0,14 мкм, при этом рост напряжения в системе не приводит к дальнейшему снижению параметра Ra. Можно предположить, что в данных условиях термическое окисление имеет влияние на морфологию поверхности, оксидный слой становится более пористым.

\section{Фазовый анализ}

На рис. 3 и 4 представлены микроструктуры поверхностного слоя образцов стали 20 после цементации в электролите на основе хлорида аммония и сахарозы.

Было установлено, что рост температуры обработки из-за большой скорости нагрева измельчает зерна феррита и перлита. Структура поверхностного слоя стали 20 после цементации и охлаждения в электролите представляет собой диффузионный слой, насыщенный углеродом. Далее следует материал основы, который представлен в виде сорбита, на что указывают микроструктуры на фотографиях поверхностного слоя и значения микротвёрдости. Сама структура сердцевины и диффузионного слоя не зависит от состава электролита. 

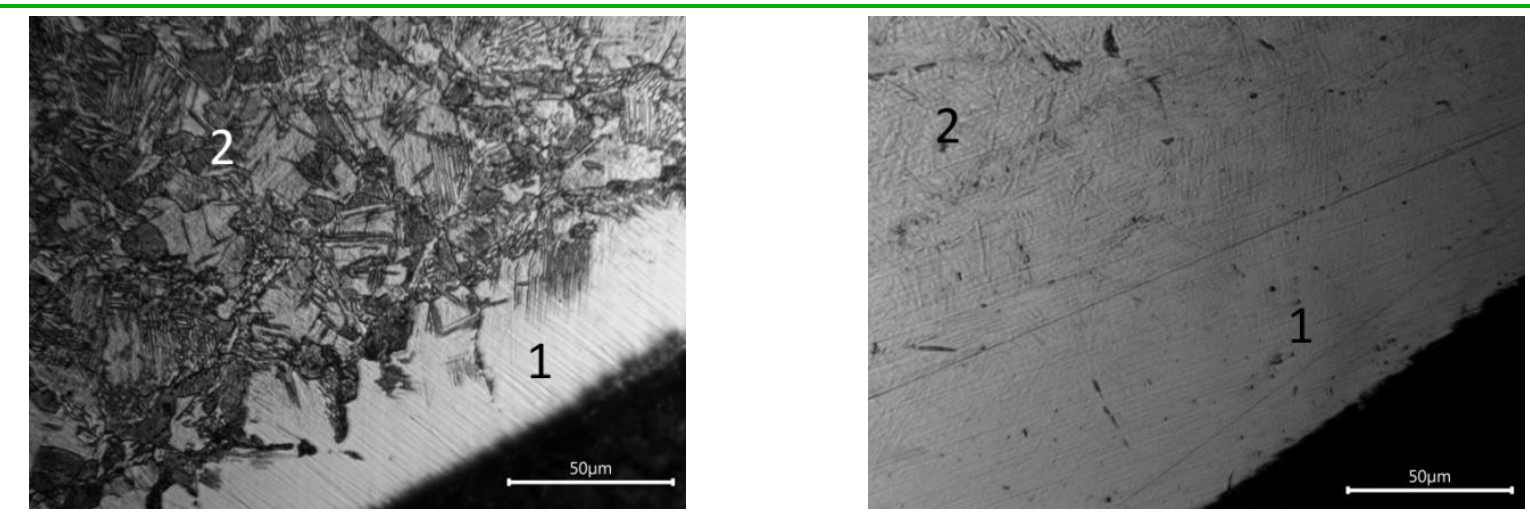

Рис. 3. Микроструктура стали 20 после цементации в электролите с равным содержанием хлорида аммония и сахарозы. Температура обработки $-750{ }^{\circ} \mathrm{C}$, закалка

Рис. 4. Микроструктура стали 20 после цементации в электролите с равным содержанием хлорида аммония и сахарозы. Температура обработки $-950{ }^{\circ} \mathrm{C}$, закалка

Поскольку коэффициент диффузии углерода в феррите и аустените растёт с повышением температуры, а при температуре $950{ }^{\circ} \mathrm{C}$ существует только аустенит [5, с. 752], было принято решение оценить толщину диффузионного слоя после обработки именно при такой температуре. В таблице 1 представлены результаты измерения толщины диффузионного слоя оптическим методом.

Таблица 1

Толщина диффузионного слоя в образцах после АЭПЦ

\begin{tabular}{|l|c|c|}
\hline УСК & Сахароза & Глицерин \\
\hline$h$, мкм & $56 \pm 1$ & $29 \pm 1$ \\
\hline
\end{tabular}

Было установлено, что после обработки в сахарозном электролите диффузионный слой почти в 2 раза больше, чем после обработки в растворе с добавлением глицерина. Это связано с тем, что в глицериновом электролите идёт более интенсивное растворение поверхностного слоя (рис. 5). 


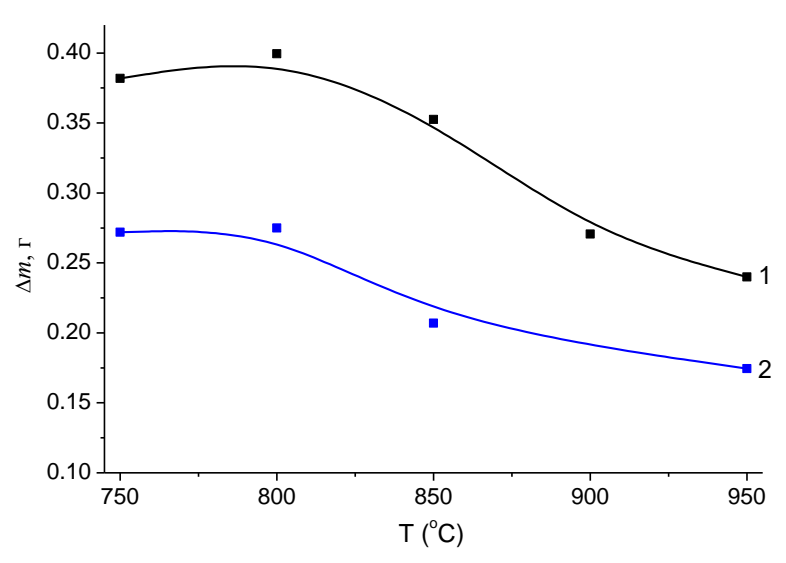

\section{Рис. 5. Зависимость убыли массы образцов от температуры обработки в растворе с добавлением глицерина (1) и сахарозы (2)}

\section{Рентгеноструктурный анализ}

Как и у необработанного образца на дифрактограммах основные пики принадлежат $\alpha-\mathrm{Fe}$, интенсивность которых незначительно снижается вследствие образования тонкого оксидного слоя. В результате большой степени переохлаждения образцов в результате закалки обнаружены пики остаточного аустенита $(\gamma-\mathrm{Fe})$. Величина пиков карбида железа $\mathrm{Fe}_{3} \mathrm{C}$ увеличивается с ростом температуры обработки, что свидетельствует об интенсификации процесса цементации и увеличении содержания углерода в поверхностном слое. Можно предположить, что промежуточные продукты распада сахарозы и глицерина в растворе различные, но конечные продукты их разложения в ПГО будут одинаковы. Вероятно, что концентрация монооксида углерода в ПГО, как одного из продуктов термодеструкции, будет определяться содержанием углерода в исходных компонентах - сахарозе и глицерине, а также их термической стойкостью.

На дифрактограммах (рис. 6) выявляется присутствие оксидов трёхвалентного железа: $\alpha-\mathrm{Fe}_{2} \mathrm{O}_{3}$ и $\gamma-\mathrm{Fe}_{2} \mathrm{O}_{3}$. В работе [3, с. 4-9] представлен возможный механизм окисления поверхности стали:

$$
3 \mathrm{Fe}+4 \mathrm{H}_{2} \mathrm{O} \leftrightarrow \mathrm{Fe}_{3} \mathrm{O}_{4}+8 \mathrm{H}^{+}+8 \mathrm{e}^{-}
$$

Однако анализ дифрактограмм показал отсутствие магнетита. Поэтому можно предположить следующий механизм образования оксидного слоя с целью объяснения его качественного состава. 


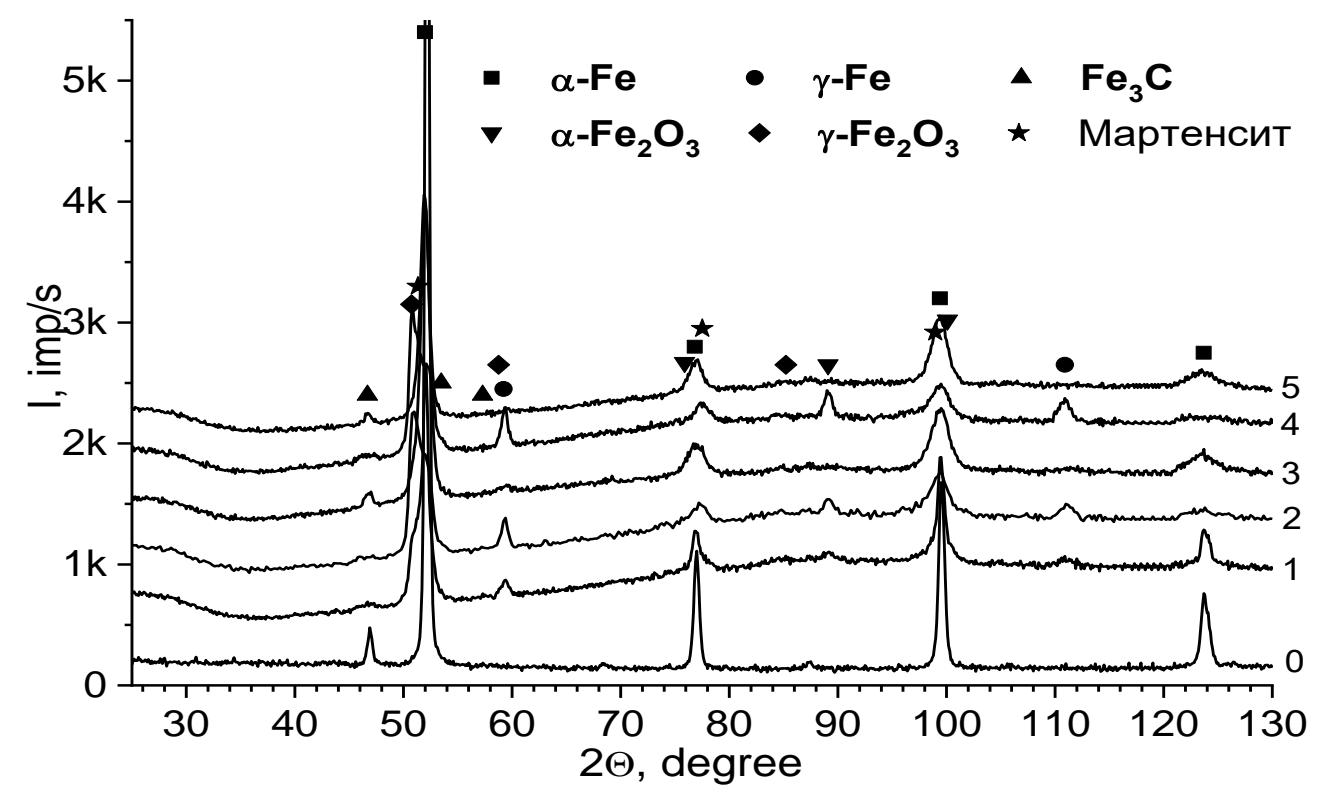

Рис. 6. Фазовый состав образцов стали 20 после АЭПЦ в электролите на основе сахарозы и закалки от температуры нагрева.

о- необработанный образец, $1-750{ }^{\circ} \mathrm{C}, 2-800{ }^{\circ} \mathrm{C}, 3-850{ }^{\circ} \mathrm{C}$, 4-900 ${ }^{\circ} \mathrm{C}, 5-950{ }^{\circ} \mathrm{C}$

Начальным этапом взаимодействия нагретой поверхности изделий с водяным паром в ПГО действительно можно описать уравнением (2). Для уточнения следует заметить, что данная реакция происходит во время АЭПЦ при температуре от $700{ }^{\circ} \mathrm{C}$, что и отвечает температурным режимам цементации. Также следует обратить внимание, что реакция (2) при повышении температуры до 900-1000 ${ }^{\circ} \mathrm{C}$ протекает как в прямом, так и в обратном направлении.

Также имеет место процесс взаимодействия самого материала основы образцов с $\mathrm{Fe}_{3} \mathrm{O}_{4}$ при высоких температурах обработки:

$$
\mathrm{Fe}_{3} \mathrm{O}_{4}+\mathrm{Fe} \rightarrow 4 \mathrm{FeO}
$$

Отсутствие оксида железа $\mathrm{FeO}$ можно объяснить его окислением при закалке, во время которой происходит схлапывание ПГО и взаимодействие раскалённой поверхности образца непосредственно с водой (4):

$$
4 \mathrm{FeO}+2 \mathrm{nH}_{2} \mathrm{O} \rightarrow 2\left(\mathrm{Fe}_{2} \mathrm{O}_{3} \cdot \mathrm{nH}_{2} \mathrm{O}\right)
$$


$\mathrm{B}$ дальнейшем при остывании кристаллогидрат $\left(\mathrm{Fe}_{2} \mathrm{O}_{3} \cdot \mathrm{nH}_{2} \mathrm{O}\right)$ распадается на $\mathrm{Fe}_{2} \mathrm{O}_{3}$ и воду. Данный состав оксидного слоя не зависит от углеродсодержащих компонентов в растворе и обусловлен только режимом охлаждения.

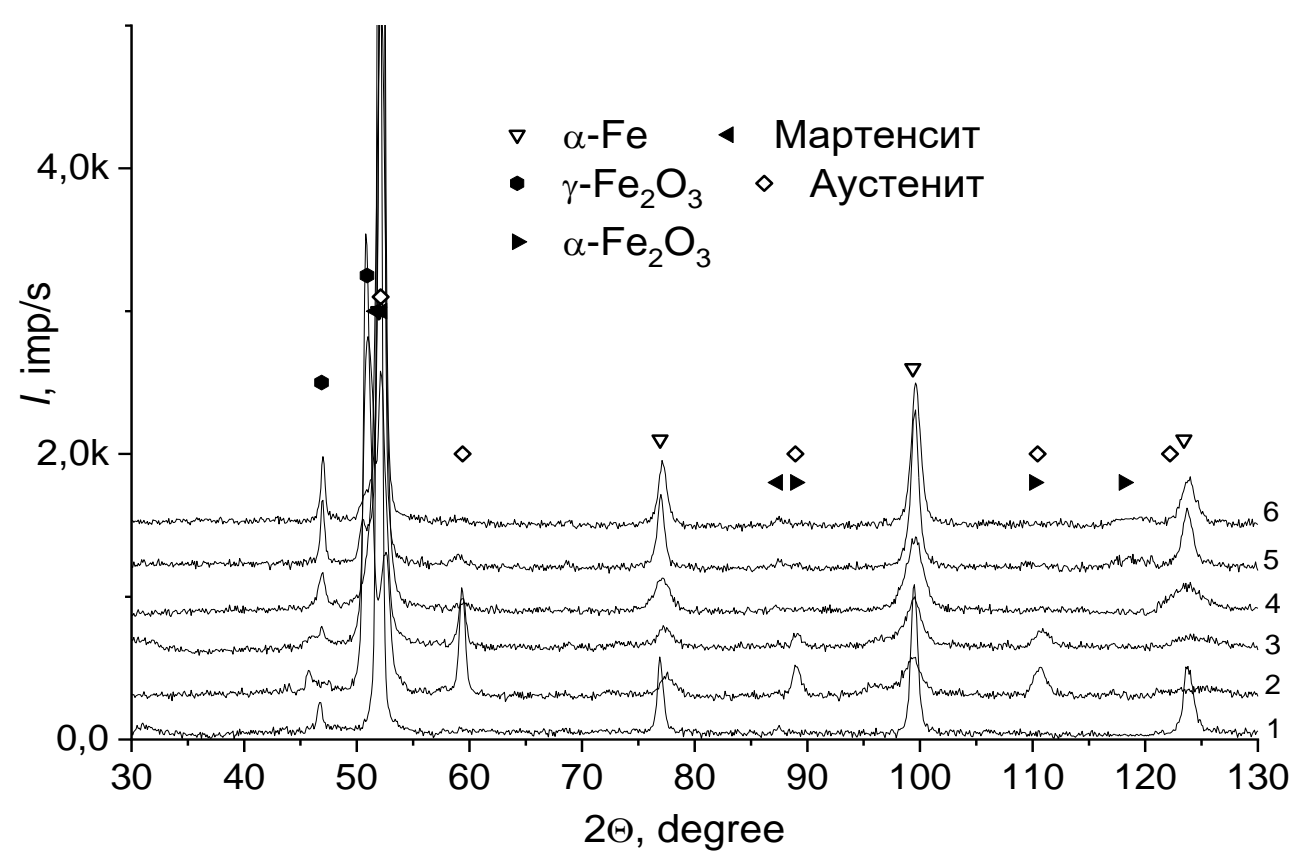

Рис. 7. Фазовый состав образцов стали 20 после АЭПЦ в электролите на основе глицерина и закалки от температуры нагрева.

1- необработанный образец, $2-750{ }^{\circ} \mathrm{C}, 3-800{ }^{\circ} \mathrm{C}, 4-850{ }^{\circ} \mathrm{C}$,

$$
5-900{ }^{\circ} \mathrm{C}, 6-950{ }^{\circ} \mathrm{C}
$$

Анализ дифрактограмм образцов после обработки в глицериновом электролите показывает несколько иные результаты. Был также выявлен гематит и маггемит, при этом интенсивность пиков гематита снижается, а маггемита увеличивается.

Учитывая постоянное интенсивное растворение поверхности образцов можно сказать, что именно реакцией (4) можно объяснить результаты фазового анализа закалённых образцов после АЭПЦ в растворах с добавлением сахарозы и глицерина.

По мере повышения температуры обработки величина пиков немного увеличивается, что говорит о некотором влиянии температуры обработки на толщину оксидного слоя. В результате измерения интенсивности пиков $\alpha-\mathrm{Fe}$ 
было установлено, что толщина оксидного слоя изменяется в пределах 2,83,3 мкм.

\section{Металлографический анализ}

На рис. 8 представлены результаты распределения микротвердости поверхностного слоя образцов стали 20, обработанных в электролите на основе сахарозы с последующей закалкой от температуры насыщения. После обработки в глицериновом электролите величины микротвёрдости поверхностного слоя будут примерно равными, однако следует заметить, различия будут лишь в толщине диффузионного слоя.
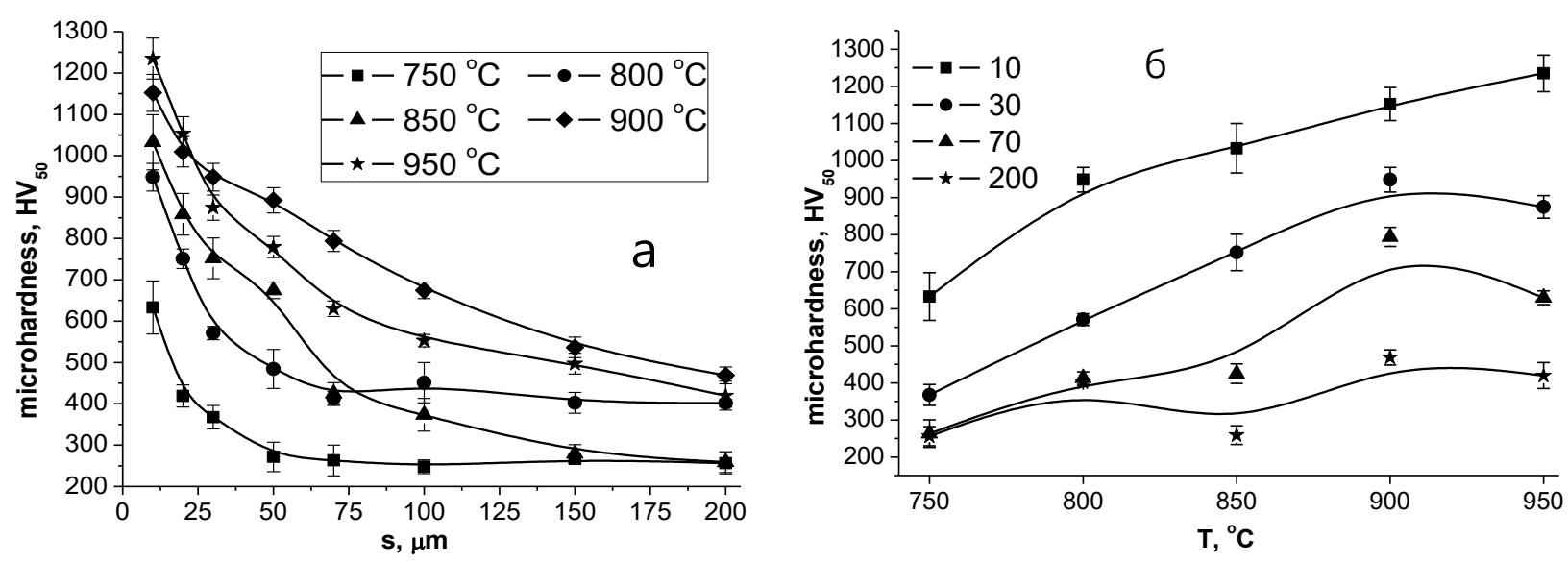

Рис. 8. Зависимость распределения микротвердости в поверхностном слое от температуры нагрева после закалки (а), зависимость микротвёрдости поверхностного слоя образцов на различной глубине (б). Обработка раствор с равным содержанием хлорида аммония и сахарозы

Из полученных данных (рис. 8а) следует, что повышение температуры обработки монотонно увеличивает значение микротвёрдости края поверхностного слоя. Также увеличивается и толщина диффузионного слоя. Наиболее вероятно, что повышение температуры цементации увеличивает интенсивность насыщения поверхности стали углеродом, как и при классической цементации. В различных литературных источниках указано, что микротвёрдость внутреннего края цементованного слоя равна $500-550 H V_{50}$. $[6$, c. 171]. По этой величине можно сделать выводы о толщине цементованного слоя (рис. 8б) и его росте.

\section{Электрохимические испытания}

В результате анодной электролитно-плазменной обработки на поверхности стальных образцов образуется слой оксидов железа. Известно, что 
оксидный слой либо несёт защитные функции, либо не несёт. Чем плотнее оксидный слой, чем лучше его сплошность, тем сильнее защитные функции оксидного слоя.

Согласно литературным данным, оксиды железа в разной степени оказывают защитное действие. Например, вюстит, обладая хорошей адгезией к железу, имеет слабые защитные свойства против коррозии, тогда как магнетит обладает большей коррозионной стойкостью. Однако магнетит имеет весьма слабую адгезию к железу, поэтому отслаивается. Далее будет рассмотрено влияние оксидного слоя на электрохимическое поведение стали 20.

Известно, что на поверхности стальных изделий оксидный слой имеет слоистую структуру: ближе к поверхности располагаются высшие оксиды [7, c.225]. Поскольку результаты рентгеноструктурного анализа показали, что в процессе обработки в сахарозном электролите и закалки от разных температур изменяется соотношение гематита и маггемита (с ростом температуры обработки и закалки до $850^{\circ} \mathrm{C}$ увеличивается доля гематита, а далее она снижается), можно предположить, что данное электрохимическое поведение поверхности стали 20 обусловлено именно соотношением гематита и маггемита.

В табл. 2 показано влияние температуры обработки и типа охлаждения на плотность тока коррозии образцов стали 20, обработанных в электролитах на основе сахарозы и глицерина.

Таблица 2

Влияние температуры обработки и типа охлаждения на плотность тока коррозии $j$, мкА/см². Коррозионная среда - водный раствор $\mathrm{Na}_{2} \mathrm{SO}_{4}$

(0,05 моль/л)

\begin{tabular}{|c|c|c|c|c|c|c|}
\hline $\begin{array}{c}\text { Температура } \\
\text { обработки }\end{array}$ & 750 & 800 & 850 & 900 & 950 & Необработ. \\
\cline { 1 - 6 } УСК & & 4,5 & 10,02 & 8,27 & 6,26 & 10,58 \\
\cline { 1 - 6 } сахароза & 2,32 & 9,94 & 7,53 & 8,53 & 11,92 & \\
\cline { 1 - 5 } глицерин & 11,73 & & & & \\
\hline
\end{tabular}

Именно соотношением гематита и маггемита можно объяснить электрохимическое поведение поверхности стали 20 после цементации в глицериновом электролите, после которой наблюдается увеличение доли маггемита и снижение доли гематита. 


\section{Выводы}

1. Установлены закономерности изменения шероховатости поверхности стали 20 после анодной электролитно-плазменной цементации в растворах с добавлением глицерина и сахарозы.

2. Были выявлены микроструктуры поверхностных слоёв стали 20 после АЭПЦ в различных электролитах, определены толщины диффузионных слоёв для максимальной температуры обработки.

3. Определен фазовый состав поверхностного слоя стали 20 после АЭПЦ при различных температурах обработки в сахарозном и глицериновом растворах.

4. Установлена линейная зависимость микротвёрдости края поверхностного слоя образцов стали 20 от температуры обработки в растворах с различными углеродсодержащими компонентами.

5. Определены коррозионные характеристики стали 20 после АЭПЦ при различных температурах процесса в электролитах с добавлением глицерина и сахарозы.

\section{Список литературы}

1. Жиров А.В., Дьяков И.Г., Белкин П.Н. Растворение и окисление углеродистых сталей при анодном нагреве в водных электролитах // Известия высших учебных заведений. Химия и химическая технология. $-2010 .-$ Т. 53. Вып. 2. - С. 89-93.

2. Суминов И.В., Белкин П.Н., Эпельфельд А.В. и др. Плазменноэлектролитическое модифицирование поверхности металлов и сплавов / Т. І. М.: Техносфера, 2011. - 464 с.

3. Дьяков И.Г., Наумов А.Р., Электронная обработка материалов, 2006, № 6, С. 4-9.

4. Кусманов С.А., Дьяков И.Г., Белкин П.Н. Зависимость характеристик анодной электрохимико-термической цементации стальных цилиндрических образцов от состава электролита // Электрохимические и электролитноплазменные методы модификации металлических поверхностей: материалы III Междунар. науч.-техн. конф. Кострома: КГУ им. Н. А. Некрасова, 2010. С. 222228.

5. Stanley I.K. «J. of Metals», 1949, № 10, p. 752. 
6. Дьяков И.Г., Наумов А.Р. К вопросу об электрохимических реакциях при анодном нагреве в водных электролитах на основе хлорида аммония // Электронная обработка материалов. - 2006. - №6. - С. 4-9.

7. Лахтин Ю. М. Материаловедение : учебник для машиностроительных вузов / Ю. М. Лахтин, В. П. Леонтьева. - 2-е изд., перераб. и доп. - М. : Машиностроение, 1980. - 493 с., ил.

8. Ангал Р. Коррозия и защита от коррозии. Пер. с англ.: Учебное пособие / Р. Ангал - 2-е изд. - Долгопрудный: Издательский дом «Интеллект», 2014. $-344 \mathrm{c}$. 